\title{
Characterisation of isolates of Haemophilus paragallinarum from Indonesia
}

\author{
S POERNOMOa ${ }^{a}$ SUTARMA $^{a}$, M RAFIEE $^{b}$ and PJ BLACKALL ${ }^{b}$
}

Objective To characterise 18 isolates of Haemophilus paragallinarum isolated from chickens in Indonesia.

Procedure The isolates were identified to species level by traditional phenotypic methods. Six of the isolates were also identified by a species-specific polymerase chain reaction. Fourteen of the isolates were examined for resistance to a panel of seven antimicrobial agents using a disc diffusion method. All 18 isolates were serotyped according to the Page scheme using reference antisera in a haemagglutination inhibition test.

Results Four of the 18 isolates were obtained from indigenous (kampung) chickens, with the remainder being from typical intensive poultry production systems. The 18 isolates were obtained from 11 outbreaks that showed the typical clinical signs of infectious coryza and 11 of the isolates were obtained from chickens that had been vaccinated with infectious coryza vaccines. All 18 isolates were confirmed as $H$ paragallinarum by biochemical testing and six isolates were also identified as $H$ paragallinarum by the polymerase chain reaction test. Eleven isolates were resistant to erythromycin and streptomycin, 10 to neomycin, eight to oxytetracycline, five isolates to doxycycline, three to sulphamethoxazoltrimethoprim but only one to ampicillin. Seven isolates were Page serovar A, four were Page serovar $B$ and seven were Page serovar $\mathrm{C}$.

Conclusion The presence of all three Page serovars (A, B and $C$ ) has been confirmed for the first time in Indonesian chickens. As the majority of the infectious coryza vaccines in use in Indonesia contain only serovar $A$ and $C$, the presence of serovar $B$ in chickens indicates that the protection by these bivalent vaccines would be reduced. The use of trivalent infectious coryza vaccines that contain serovars $A, B$ and $C$ is recommended for use in Indonesia.

Aust Vet J 2000;78:759-762

Key words: Poultry, Haemophilus paragallinarum, serological characterisation, Page scheme

$\mathrm{H}$

aemophilus paragallinarum is the causative agent of infectious coryza, a disease of the upper respiratory tract of chickens. ${ }^{1}$ The clinical signs of the disease include nasal discharge, facial swelling and a reduction in feed and water consumption. ${ }^{1}$ Infectious coryza in poultry is a disease of economic significance in many parts of the world with the greatest economic losses resulting from an increased number of culls and marked reduction (10 to $40 \%$ ) in egg production. ${ }^{1}$

${ }^{a}$ Research Institute for Veterinary Science, Bogor 16114, Indonesia

${ }^{\mathrm{b}}$ Agency for Food and Fibre Sciences, Department of Primary Industries, Animal Research Institute, Yeerongpilly, Queensland 4105
The first serological classification of $\mathrm{H}$ paragallinarum was performed in 1962 by Page who recognised three different serovars, termed A, B and C. ${ }^{2}$ The Page scheme has been widely used in many parts of the world. ${ }^{1} \mathrm{H}$ owever, other than studies performed in Japan, there have been only a few, limited serological characterisation studies performed in Asia. There have been studies performed in China, with all 29 isolates shown to be serovar $A, 3,4,5 \mathrm{M}$ alaysia, with all 10 isolates being serovar $A,{ }^{6}$ the Philippines, with one isolate each of serovar A, B and $C^{7}$ and Taiwan, with both isolates being serovar $A .{ }^{8}$

In Indonesia, the isolation of $\mathrm{H}$ paragallinarum has been reported in $1975,{ }^{9} 1978^{10}$ and $1987 .{ }^{11}$ Unfortunately, none of the isolates from these studies were maintained and, therefore, there is no knowledge of the serovars to which they belonged. Takagi et al12 reported the isolation of three $\mathrm{H}$ paragallinarum strains in Indonesia, two of which were identified as serovar A and the other as serovar $C$.

In Indonesia, infectious coryza has become a major problem with affected chickens, including indigenous (kampung) chickens, being of all ages. Imported commercial inactivated vaccines are widely used for the prevention of the disease. $\mathrm{H}$ owever, there is considerable field evidence that suggests that vaccine failure might be occurring.

In this paper, we present the results of a characterisation study of $18 \mathrm{H}$ paragallinarum isolates obtained from a number of outbreaks of infectious coryza in several parts of Indonesia between 1991 and 1999.

\section{M aterials and methods}

Bacteria

A total of 18 isolates of $\mathrm{H}$ paragallinarum were examined. All of the isolates were obtained from outbreaks of infectious coryza in broilers, layers and kampung chickens, between 1991 and 1999 from West Java (thirteen isolates), Central Java (two isolates) and Lampung in Sumatera (three isolates). As well, reference strains, 0083 (Page serovar A), 0222 (Page serovar B) and $M$ odesto (Page serovar $C$ ) were used. These reference strains were supplied from the culture collection held at the Animal Research Institute, Australia. Following initial isolation, all of the isolates were inoculated into yolk sac of 6- to 7-day-old embryonating chicken eggs (obtained from flocks known to be free of $\mathrm{H}$ paragallinarum). After $24 \mathrm{~h}$, the infected yolk sac was harvested and dispensed in $0.5 \mathrm{~mL}$ volumes in ampoules for freeze drying.

Media

Blood agar with $5 \%$ sheep's blood cells was used for both isolation and for the examination of the satellite phenomenon with a feeder culture of Staphylococcus hyicus. ${ }^{13}$ Test medium 
agar supplemented with $5 \%(\mathrm{v} / \mathrm{v})$ oleic albumin complex, $1 \%$ $(\mathrm{v} / \mathrm{v})$ chicken serum, $0.01 \%(\mathrm{w} / \mathrm{v})$ nicotinamide adenine dinucleotide (NAD) was used for growth of the cultures and was prepared as previously described. ${ }^{14}$ This medium, called TM/SN, was used for the preparation of inocula for biochemical and other tests. Liquid media were incubated aerobically, while agar plates were incubated under increased $\mathrm{CO}_{2}$ tension (approximately $10 \%$ ). All incubation was at $37^{\circ} \mathrm{C}$.

\section{Fermentation of carbohydrates}

A plate fermentation method ${ }^{15}$ was used for the detection of acid production from the following carbohydrates: galactose, glucose, lactose, maltose, mannitol, sorbitol, sucrose, trehalose and xylose. A $48 \mathrm{~h}$ culture of each isolate was suspended in phosphate buffered saline (PBS, pH 7.5) and the fermentation plates were inoculated with these suspensions. The fermentation patterns of all 18 field isolates and the three reference strains of $\mathrm{H}$ paragallinarum were determined.

\section{Other biochemical tests}

The field isolates that were tested for carbohydrate fermentation were also tested for a range of other properties. Indole production was tested according to Cowan ${ }^{16}$ with the modification that the basal medium were supplemented with $1 \%(\mathrm{v} / \mathrm{v})$ chicken serum and $0.01 \%(w / v)$ NAD. The presence of catalase, the requirement for NADH and pigment production were performed as described previously ${ }^{13}$ while the requirement for haemin was determined according to Schalm and Beach. ${ }^{17}$

\section{Polymerase chain reaction test}

Six field isolates were tested using a polymerase chain reaction (PCR) test known to be specific for $\mathrm{H}$ paragallinarum. ${ }^{18}$ The test was performed using colony preparations as previously described. 18
Antimicrobial drug resistance

The sensitivity of 14 field isolates and the three $\mathrm{H}$ paragallinarum reference strains for seven antimicrobial drugs (ampicillin $10 \mathrm{mg}$ per disc, doxycycline $30 \mathrm{mg}$, erythromycin $15 \mathrm{mg}$, neomycin $30 \mathrm{mg}$, oxytetracyclin $30 \mathrm{mg}$, streptomycin $10 \mathrm{mg}$ and sulfamethoxazol-trimethoprim $25 \mathrm{mg}$ ) were tested using a standardised disc-diffusion method. ${ }^{19} \mathrm{M}$ ueller $\mathrm{H}$ inton agar supplemented with $5 \%(\mathrm{v} / \mathrm{v})$ oleic albumin complex, $1 \%$ $(\mathrm{v} / \mathrm{v})$ chicken serum and $0.01 \%(\mathrm{w} / \mathrm{v})$ nicotinamide adenine dinucleotide was used. The inoculum was prepared from fresh overnight cultures and adjusted to a density of equivalent to that of a $0.5 \mathrm{M}$ acFarland Standard. The suspension was then swab inoculated on the modified Mueller $\mathrm{H}$ inton agar, the antimicrobial discs ( 0 xoid Unipath Ltd, Basingstoke, UK) placed on the agar surface and the plate incubated at $37^{\circ} \mathrm{C}$ for $24 \mathrm{~h}$ under $5 \% \mathrm{CO}_{2}$. The diameter of the zone of inhibition was measured. A reference strain of Escherichia coli (AT CC 25922) was used as described above, as well as being tested on unsupplemented $\mathrm{M}$ ueller $\mathrm{H}$ inton agar. All tests were performed twice. The interpretive criteria used for determining if isolates were sensitive or resistant to the various antimicrobial agents were those recommended by the $\mathrm{N}$ ational Consultative Committee on Laboratory Standards. ${ }^{20}$

\section{Serological characterisation}

The 18 isolates and three of the reference strains of $H$ paragallinarum $(0083,0222$ and M odesto, serovar A, B and C respectively) were serotyped, with antisera produced at the Animal Research Institute, ${ }^{21}$ according to the Page scheme ${ }^{2}$ using a haemagglutination-inhibition test. ${ }^{22}$

\section{Results}

The available field information on the 18 isolates examined in this study is presented in Table 1.

Table 1. Field information and serotyping results for the 18 Haemophilus paragallinarum isolates used in this study.

\begin{tabular}{|c|c|c|c|c|c|c|c|c|}
\hline Code & Year & Farm & Flock size & Chicken Type & Age (wks) & Vaccinated $^{a}$ & Region & Serovar \\
\hline $18 / 2$ & 1991 & $A$ & 70,000 & Broiler Multi-age & 5 & No & Bogor & $A$ \\
\hline $\mathrm{SH}_{2}$ & 1992 & $\mathrm{~B}$ & 12,000 & Layer Multi-age & 35 & Yes (2) & Lampung & $A$ \\
\hline $\mathrm{SH}_{9}$ & 1992 & $\mathrm{~B}$ & 6,000 & Layer Multi-age & 8 & Yes (1) & Lampung & A \\
\hline $\mathrm{SH}_{10}$ & 1992 & $\mathrm{~B}$ & 6,000 & Layer Multi-age & 20 & Yes (2) & Lampung & $A$ \\
\hline $16 \mathrm{CMG} 1^{\mathrm{b}}$ & 1993 & C & 1,200 & Kampung & 24 & No & Ciamis & A \\
\hline$A_{1}$ & 1997 & $E$ & 5,000 & Broiler Breeder & 21 & Yes (2) & Tangerang & $\mathrm{C}$ \\
\hline $\mathrm{A}_{2}$ & 1997 & $E$ & 5,000 & Broiler Breeder & 24 & Yes (2) & Tangerang & C \\
\hline $\mathrm{A}_{3}$ & 1997 & $E$ & 5,000 & Broiler Breeder & 34 & Yes (2) & Tangerang & C \\
\hline $\mathrm{A}_{4}$ & 1997 & $E$ & 5,000 & Broiler Breeder & 38 & Yes (2) & Tangerang & C \\
\hline$A D_{1}$ & 1997 & $\mathrm{~F}$ & 5,000 & Broiler Breeder & 24 & Yes (2) & Sukabumi & C \\
\hline$A D_{2}$ & 1997 & $\mathrm{~F}$ & 5,000 & Broiler Breeder & 24 & Yes (2) & Sukabumi & C \\
\hline $\mathrm{AD}_{3}$ & 1997 & $\mathrm{~F}$ & 5,000 & Broiler Breeder & 24 & Yes (2) & Sukabumi & C \\
\hline $\mathrm{B} 11.1^{\mathrm{b}}$ & 1998 & $\mathrm{G}$ & 60,000 & Broiler & 7 & No & Bogor & A \\
\hline $\mathrm{C} 1.1^{\mathrm{b}}$ & 1998 & $\mathrm{H}$ & 70,000 & Layer Multi-age & 15 & Yes (1) & Cianjur & $\mathrm{B}$ \\
\hline $\mathrm{AK}_{2}^{\mathrm{b}}$ & 1999 & 1 & 19 & Kampung Multi-age & 4 & No & Bogor & $\mathrm{B}$ \\
\hline $\mathrm{AkBur}_{4}{ }^{\mathrm{b}}$ & 1999 & $J$ & 25 & Kampung Multi-age & 8 & No & Bogor & $\mathrm{B}$ \\
\hline $\mathrm{AkPar}_{4}{ }^{\mathrm{b}}$ & 1999 & $\mathrm{~K}$ & 35 & Kampung Multi-age & 8 & No & Bogor & $\mathrm{B}$ \\
\hline
\end{tabular}

a Vaccinated = Vaccinated with a commercial infectious coryza vaccine containing only serovars $A$ and $C$. Number in brackets is the number of doses.

b Indicates that the isolate was identified by both conventional and PCR methods and also serotyped. All the other isolates were identified by conventional methods only as well as being serotyped. 
All the field isolates required NAD but not haemin for growth and showed satellitic growth on blood agar. All 18 isolates lacked catalase activity, did not produce a yellow pigment and were Gram negative rods. The isolates were all nonhaemolytic on blood agar and did not produce indole. All 18 isolates produced acid from glucose but not from galactose, lactose, trehalose or xylose. Of the 18 isolates tested, eight did not ferment maltose, one did not ferment mannitol and one did not ferment mannitol, sorbitol or sucrose. As all 18 field isolates were similar to the reference strains of $\mathrm{H}$ paragallinarum, all 18 were identified as $\mathrm{H}$ paragallinarum. The three reference strains of $\mathrm{H}$ paragallinarum gave the same carbohydrate fermentation patterns as reported previously. 13

Six of the isolates yielded a D N A product of the expected size $(0.5 \mathrm{~kb})$, in the H P-2 PCR for H paragallinarum. On the basis of this result, all six isolates were identified as $\mathrm{H}$ paragallinarum.

In the antimicrobial sensitivity testing, E coli strain ATCC 25922 gave the expected results, on both modified and normal $\mathrm{M}$ ueller-H inton agar. Table 2 shows the results of testing the 14 field isolates of $\mathrm{H}$ paragallinarum with all seven antimicrobial agents.

The three reference strains of $\mathrm{H}$ paragallinarum, 0083, 0222 and M odesto, were correctly serotyped as serovar A, B and C respectively. The overall serotyping results, with 12 isolates being serotyped in Indonesia and six in Australia, were as follows: seven isolates were Page serovar $A$, four isolates were Page serovar $B$ and seven isolates were Page serovar $C$.

\section{Discussion}

The Indonesian isolates of $\mathrm{H}$ paragallinarum tested by phenotypic methods in this study showed, in general, the typical properties of $\mathrm{H}$ paragallinarum. We found variation in the ability of the field isolates to produce acid from four carbohydrates - maltose, mannitol, sorbitol and sucrose. Similar variation has been reported previously. ${ }^{23}$ It would appear that there is little variation in the biochemical properties of $\mathrm{H}$ paragallinarum as isolates from such diverse parts of the world as Argentina ${ }^{24}$, Australia ${ }^{13}$, China $^{4}$ and the United States of America ${ }^{25}$ all show a similar carbohydrate fermentation pattern.

As $\mathrm{H}$ paragallinarum isolates do not grow on the standard media used in antimicrobial sensitivity testing, we used supplemented Mueller $\mathrm{H}$ inton agar, which is capable of supporting the growth of $\mathrm{H}$ paragallinarum. The use of supplemented M ueller $\mathrm{H}$ inton agar had no major impact on the results of the reference $E$ coli strain (data not shown) so we regard the results obtained for the six $\mathrm{H}$ paragallinarum isolates as valid. We found a frequent occurrence of resistance to erythromycin, neomycin and streptomycin. 0 thers have also reported that $\mathrm{H}$ paragallinarum isolates can be resistant to streptomycin. $12,25,26,27$

We found four Indonesian isolates to be serovar $B$, the first time this serovar has been recognised in this country. The only previous serological characterisation of Indonesian isolates of $\mathrm{H}$ paragallinarum reported the presence of serovars $A$ and $C .{ }^{12}$ O ur finding of serovar $B$ has several important practical implications. Although there has been some confusion in the earlier literature, there is now compelling evidence that serovar $B$ is a true serovar. ${ }^{28}$ Further, Page serovar $B$ isolates show little crossimmunity with serovars $A$ and $B .{ }^{29}$ This means that vaccines based on serovar $A$ or $C$ have little chance of providing protection against a Page serovar $B$ challenge. Additionally, there is evidence, within Page serovar $B$, of limited cross-protection
Table 2. Sensitivity to seven antimicrobial drugs of 14 field isolates of Haemophilus paragallinarum from 1991 to 1999.

\begin{tabular}{|c|c|c|c|c|c|c|c|c|}
\hline \multirow[t]{2}{*}{ Strain } & \multirow[t]{2}{*}{ Year } & \multicolumn{7}{|c|}{ Sensitivity to antimicrobial drugs ${ }^{a}$} \\
\hline & & $\begin{array}{c}\text { AMP } \\
(10 \mu \mathrm{g})\end{array}$ & $\begin{array}{c}\text { DO } \\
(30 \mu \mathrm{g})\end{array}$ & $\begin{array}{c}\text { ERY } \\
(15 \mu \mathrm{g})\end{array}$ & $\begin{array}{c}\text { NEO } \\
(30 \mu \mathrm{g})\end{array}$ & $\begin{array}{c}\text { OT } \\
(30 \mu \mathrm{g})\end{array}$ & $\begin{array}{c}S \\
(10 \mu \mathrm{g})\end{array}$ & $\begin{array}{c}\text { SXT } \\
(25 \mu \mathrm{g})\end{array}$ \\
\hline $18_{2}$ & 1991 & $S^{b}$ & S & $\mathrm{R}$ & $\mathrm{R}$ & S & $\mathrm{R}$ & $\mathrm{R}$ \\
\hline $16 \mathrm{CMG}_{1}$ & 1993 & S & S & $S$ & S & S & S & S \\
\hline $\mathrm{SH}_{2}$ & 1992 & $S$ & $\mathrm{~S}$ & $S$ & S & $S$ & $\mathrm{~s}$ & $\mathrm{~s}$ \\
\hline $\mathrm{SH}_{9}$ & 1992 & S & $\mathrm{S}$ & S & S & S & S & S \\
\hline $\mathrm{SH}_{10}$ & 1992 & S & S & $\mathrm{R}$ & $\mathrm{R}$ & S & $\mathrm{R}$ & S \\
\hline$A D_{1}$ & 1997 & S & $\mathrm{R}$ & $\mathrm{R}$ & $\mathrm{R}$ & $\mathrm{R}$ & $\mathrm{R}$ & S \\
\hline$A D_{2}$ & 1997 & $S$ & $\mathrm{R}$ & $\mathrm{R}$ & $\mathrm{R}$ & $\mathrm{R}$ & $\mathrm{R}$ & S \\
\hline$A_{1}$ & 1997 & S & $\mathrm{R}$ & $\mathrm{R}$ & $\mathrm{R}$ & $\mathrm{R}$ & $\mathrm{R}$ & S \\
\hline $\mathrm{A}_{3}$ & 1997 & $S$ & $\mathrm{R}$ & $\mathrm{R}$ & $\mathrm{R}$ & $\mathrm{R}$ & $\mathrm{R}$ & $S$ \\
\hline B11.1 & 1998 & $S$ & $S$ & $\mathrm{R}$ & $S$ & $S$ & $\mathrm{R}$ & $S$ \\
\hline C. 1 & 1998 & $S$ & $S$ & $\mathrm{R}$ & $\mathrm{R}$ & $\mathrm{R}$ & $\mathrm{R}$ & $S$ \\
\hline $\mathrm{AK}^{2}$ & 1999 & $\mathrm{R}$ & $\mathrm{R}$ & $\mathrm{R}$ & $\mathrm{R}$ & $\mathrm{R}$ & $\mathrm{R}$ & $\mathrm{R}$ \\
\hline AKBur $_{5}$ & 1999 & $S$ & 1 & $\mathrm{R}$ & $\mathrm{R}$ & $\mathrm{R}$ & $\mathrm{R}$ & S \\
\hline $\mathrm{AKPar}_{4}$ & 1999 & $S$ & I & $\mathrm{R}$ & $\mathrm{R}$ & $\mathrm{R}$ & $\mathrm{R}$ & $\mathrm{R}$ \\
\hline
\end{tabular}

${ }_{\mathrm{A}} \mathrm{mp}=$ Ampicillin, $\mathrm{DO}=$ Doxycycline, $\mathrm{ERY}=$ Erythromycin, NEO = Neomycin, $\mathrm{OT}=$ Oxtetracycline, $\mathrm{S}=$ Streptomycin, $\mathrm{SXT}=$ Sulphamethoxazoletrimethoprim. The amount of antimicrobial agent in the disc is indicated in parenthesis.

between some isolates. ${ }^{29} \mathrm{H}$ ence, our finding of serovar B in both commercial and kampung chickens indicates that there is a need for careful selection of the seed strains used to produce infectious coryza vaccines for use in Indonesia. In particular, unless there is specific knowledge of the serovars present in the target population, the use of bivalent vaccines that contain only Page serovars $\mathrm{A}$ and $\mathrm{C}$ cannot be recommended in Indonesia.

The finding of Page serovar $\mathrm{B} H$ paragallinarum in Indonesian chickens has important implications for the Australian poultry industry. Isolates of Page serovar B have never been found in any of the serological characterisation studies performed on Australian isolates of $\mathrm{H}$ paragallinarum. 21,30-32 $\mathrm{H}$ ence, Page serovar $\mathrm{B} H$ paragallinarum can be regarded as an exotic agent. As well, all the infectious coryza vaccines used in Australia contain only Page serovar $A$ and $C$, meaning any entry of Page serovar $B$ would result in vaccine failures. $H$ ence, the presence of Page serovar $B$ in a near neighbour is an important reminder of the need for tight biosecurity.

Infectious coryza is often regarded as a disease that has the greatest impact in intensively raised chickens. Indeed, the disease is not often considered when working with village chickens. Hence, our finding of confirmed isolates of $\mathrm{H}$ paragallinarum in kampung chickens is a reminder that the disease can be present in less intensive production systems. O ur finding of isolates of $\mathrm{H}$ paragallinarum in kampung chickens supports the earlier serological work of Takagi et al. ${ }^{12}$ who found a high prevalence of antibodies to serovar $A$ and $C$ in kampung chickens. The potential importance of coryza in less intensive systems is supported by the work of Thitisak et al ${ }^{33}$ who found that infectious coryza killed more chickens than any other disease, including $\mathrm{N}$ ewcastle disease, in Thai village chickens less than 2 months old or more than 6 months old. It was only in the 2 to 6 months age group that other diseases such as N ewcastle D isease and pasteurellosis killed more chickens. ${ }^{33}$ 
Fourteen of the isolates in this study were from outbreaks of infectious coryza in seven different commercial flocks. Of these seven outbreaks, four occurred despite the use of infectious coryza vaccines. In one of these outbreaks, the isolate was serovar $B$ while the vaccine used was a serovar $A$ /serovar $C$ bivalent product. This mis-match of challenge serovar with vaccine is the most likely explanation for this case of vaccine failure. 0 ther explanations such as improper vaccine handling or improper vaccination technique may also have played a role in some of these apparent vaccine failures. O verall, there is a need for the active investigation of suspect infectious coryza vaccine failures, including the isolation and serotyping of suspect $\mathrm{H}$ paragallinarum isolates.

\section{Acknowledgments}

The provision of funds by $\mathrm{Mr}$. Yapto $\mathrm{N}$ azarudin from Kepuhardjo, Karangploso, $M$ alang East Java to support this study is gratefully acknowledged.

\section{References}

1. Blackall PJ, Matsumoto M, Yamamoto R. Infectious coryza. In: Calnek BW, Barnes HJ, Beard CW, McDougald LR, Saif YM, editors. Diseases of Poaultry. lowa State University Press, Ames, lowa, 1997;179-190.

2. Page LA. Haemophilus infections in chickens. 1. Characteristics of 12 Haemophilus isolates recovered from diseased chickens. Am J Vet Res 1962;23:85-95.

3. Feng W. Isolation and identification of the infectious coryza pathogen in Beijing (in Chinese). Microbiol (China) 1987;??:216-219.

4. Chen X, Zhang P, Blackall PJ, Feng W. Characterization of Haemophilus paragallinarum isolates from China. Avian Dis 1993:37:574-576.

5. Miflin JK, Chen X, Blackall PJ. Molecular characterisation of isolates of Haemophilus paragalinarum from China by ribotyping. Avian Pathol 1997;27:119-127.

6. Zaini MZ, Iritani Y. Serotyping of Haemophilus paragallinarum in Malaysia. J Vet Med Sci 1992;54:363-365.

7. Nagaoka K, De Mayo A, Takagi M, Ohta S. Characterization of Haemophilus paragallinarum isolated in the Philippines. J Vet Med Sci 1994;56:1017-1019. 8. Lin JA, Shyu CL, Yamaguchi T, Takagi M. Characterization and pathogenicity of Haemophilus paragallinarum serotype $\mathrm{C}$ in local chicken of Taiwan. J Vet Med Sci 1996;58:1007-1009.

9. Sri Poernomo. Haemophilus gallinarum pada ayam. I. Isolasi Haemophilus gallinarum pada ayam. Bull LLPH 1975;8-9:11-22.

10. Hardjoutomo S. Snot menular pada ayam petelur. I. Wabah Snot menular pada peternakan sambilan di Kabupaten Bogor. Penyakit Hewan 1985;30:13-18. 11. Sri Poernomo, Ronohardjo P. Efficiacy of Casumix plus in broilers with coryza (Haemophilus paragallinarum infection). Penyakit Hewan 1987;19:6-10. 12. Takagi M, Takahashi T, Hirayama N et al. Survey of infectious coryza of chickens in Indonesia. J Vet Med Sci 1991;53:637-642.
13. Blackall PJ, Reid GG. Further characterization of Haemophilus paragallinarum and Haemophilus avium. Vet Microbiol 1982;7:359-367.

14. Reid GG, Blackall PJ. Comparison of adjuvants for an inactivated infectious coryza vaccine. Avian Dis 1987:31:59-63.

15. Blackall PJ. An evaluation of methods for the detection of carbohydrate fermentation patterns in avian Haemophilus species. J Microbiol Methods 1983;1:275-281.

16. Cowan ST. Cowan and Steel's Manual for the Identification of Medical Bacteria. Cambridge University Press, Cambridge, 1974:238.

17. Schalm OW, Beach JR. Studies on infectious coryza of chickens with special reference to its aetiology. Poult Sci 1936;15:473-482.

18. Chen X, Miflin JK, Zhang P, Blackall PJ. Development and application of DNA probes and PCR tests for Haemophilus paragallinarum. Avian Dis 1996;40:398-407.

19. Simmons GC, Craven JA. Antibiotic sensitivity tests using the disc method. SCA Animal Health Committee, Australian Bureau of Animal Health. 1980.

20. Anonymous. National Committee for Clinical Laboratory Standards. Villanova, USA. 1984.

21. Thornton AM, Blackall PJ. Serological classification of Australian isolates of Haemophilus paragallinarum. Aust Vet J 1984;61:251-253.

22. Blackall PJ, Eaves LE, Aus G. Serotyping of Haemophilus paragallinarum by the Page scheme: comparison of the use of agglutination and hemagglutination-inhibition tests. Avian Dis 1990;34:643-645.

23. Blackall PJ, Eaves LE, Rogers DG. Biotyping of Haemophilus paragallinarum by hemagglutination serotyping, and carbohydrate fermentation, and antimicrobial drug resistance patterns. Avian Dis 1989;33:491-496.

24. Terzolo HR, Paolicchi FA, Sandoval VE, Blackall PJ, Yamaguchi T, Iritani Y. Characterization of isolates of Haemophilus paragallinarum from Argentina. Avian Dis 1993;37:310-314

25. Rimler RB. Studies of the pathogenic avian haemophili. Avian Dis 1979:23:1006-1018.

26. Blackall PJ. Antimicrobial drug resistance and the occurrence of plasmids in Haemophilus paragallinarum. Avian Dis 1988;32:742-747.

27. Reece RL, Coloe PJ. The resitance to anti-microbial agents of bacteria isolated from pathological conditions of birds in Victoria, 1978 to 1983. Aust Vet J 1985;62:379-381.

28. Yamaguchi T, Blackall PJ, Takigami S, Iritani Y, Hayashi Y. Pathogenicity and serovar-specific hemagglutinating antigens of Haemophilus paragallinarum serovar B strains. Avian Dis 1990;34:964-968.

29. Yamaguchi T, Blackall PJ, Takigami S, Iritani Y, Hayashi Y. Immunogenicity of Haemophilus paragallinarum serovar B strains. Avian Dis 1991;35:965-968. 30. Blackall PJ, Eaves LE. Serological classification of Australian and South African isolates of Haemophilus paragallinarum. Aust Vet J 1988;65:362-363.

31. Eaves LE, Rogers DG, Blackall PJ. Comparison of hemagglutinin and agglutinin schemes for the serological classification of Haemophilus paragallinarum and proposal of a new hemagglutinin serovar. J Clin Microbiol 1989;27:1510-1513.

32. Blackall PJ, Eaves LE, Rogers DG. Proposal of a new serovar and altered nomenclature for Haemophilus paragallinarum in the Kume hemagglutinin scheme. J Clin Microbiol 1990;28:1185-1187.

33. Thitisak W, Janviriyasopak O, Morris RS, Srihakim S, Kruedener RV. Causes of death found in an epidemiological study of native chickens in Thai villages. Acta Vet Scand 1988;84(Suppl):200S-202S

(Accepted for publication 2 June 2000) 